\title{
Artificial Intelligence and Spirituality
}

\author{
José Fernando Calderero Hernández* \\ Universidad Internacional de La Rioja, Logroño (Spain)

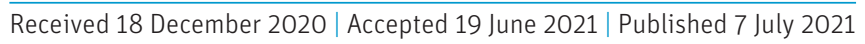

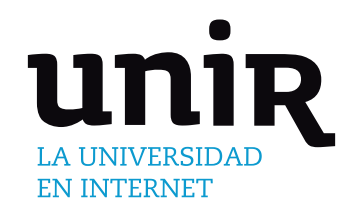

\section{ABSTRACT}

\section{KEYWORDS}

Drawing from a conceptual review of the terms 'mind', 'intelligence', 'spirit', 'spirituality', 'spiritual intelligence' and their possible interrelations, an approach to the concept 'human nature' is made in relation to transhumanism and post-humanism. In addition, through a reflection on the nature and meaning of the terms 'datum', 'coding', 'language', 'energy', 'concrete', and 'abstract', some dimensions of 'artificial intelligence' (AI) and their analogies and differences with 'the spiritual' are shown. After a brief foray into the concept of 'reality' and its probable 'fuzziness', we discuss their intrinsic and inherent mutability, and the possible existential dependence of some of their parts on the intentional activity of personal beings. We point out the dangers, for intellectual rigor and therefore for life in general, and human life in particular, of reductionist interpretations of reality that, arguing at having been scientifically proven, are intended to provide a closed and indisputable explanation of facts and phenomena of diverse aetiology, ignoring the need for 'management of the unknown'. Consequently, an open, synergetic, harmonious vision of the role of technology and the humanities, especially those most focused on the study of the intangible, is necessary for the progress of knowledge and, therefore, for the mutually beneficial care of humanity and nature.
Intelligence, Spirituality, Artificial Intelligence (AI).

\section{Introduction}

TF we were to imagine humanity as a single family trying to thrive Lby exploiting available natural resources in an intelligent manner, in alignment with the goals of the United Nations 2030 Agenda for Sustainable Development (United Nations, 2015) [1], to achieve the objectives of 'caring for our common home', in the words of Pope Francis (2015) [2], it would seem reasonable to stockpile all available goods and resources for efficacy and efficiency. It would be advisable to use all available resources and avoid any reductionism that might, due to narrow-mindedness, compromise the success of the endeavour; in this respect, the huge importance of abundant intangible resources available to humans, such as talent, creativity, imagination, etc. many of which, if not all, are located within what we might call the 'human spirit' - must be underscored. On the other hand, these very talents have prompted the emergence of tangible artefacts, subject to procedures and methods inherent to experimental sciences but with a 'modus operandi' quite similar to human intelligence, resulting in their being called artificial intelligence in a broad sense.

Following the logic of the benefits of pooling resources, it seems advisable and necessary to contribute to it, in an attempt to provide potentially valuable perspectives here by exploring different aspects of both worlds.

The thesis of the article consists in pointing out that AI can help to minimize negative consequences of the important dose of ambiguity, polysemy and synonymy existing in some of the relevant terms necessary both in the field of spirituality and in that of AI.

${ }^{*}$ Corresponding author.

E-mail address: josefernando.calderero@unir.net
We will argue how the difficulty of precisely defining the relevant keywords for the study of both topics, and the concepts of blurred reality and interdimensional unity of reality can be useful to show the relevant role that $\mathrm{AI}$ can, and should, play in the advance of those areas traditionally considered as remote from experimental science and technique and contribute to disseminating the need for effective synergy between technical advances in AI and the conceptual and methodological needs of the disciplines that study the intangible.

We consider it relevant to reflect on the contributions that AI can make to the study of spirituality since we understand that this is seriously harmed by the limitations imposed by language, which force both to dispense with relevant and significant nuances and dimensions and to only consider suitable those research results that can be expressed with absolute precision. We understand that the great information processing capacity of AI can allow, to a certain degree, the exceeding of the aforementioned limits.

\section{A Conceptual Review}

Do the words we use describe unequivocally and with absolute precision the external, internal, ontological characteristics of what is, or is considered, real (or whose possible existence is, at least, not discarded) and could be deemed pre-existing, or must we settle for using them as mere approximations, we might say asymptotic, of the 'realities' they attempt to describe?

If we expect to radically answer this question, we must, in each case, determine exactly all the applicable dimensions of the object under consideration, a presumably unattainable endeavour even within the limits of the dimensional spectrum recordable by human senses and technology, at least at the current degree of development of both of those 'resources'. If, in order to consider an object perfectly described, 
we demanded that the descriptor element, word, code, symbol, etc. include all the object's dimensions, we would find ourselves faced with huge, presumably insurmountable, operational difficulties. Imagine, for example, that we needed to convey the 'perfect' description of a simple piece of bread across a channel that only used written text as code. With certain limitations, we could describe its colour (omitting logically the nuances of its different areas and using only the words describing the main colours), its size (renouncing a detailed description of the outline of its edges, supposing the word 'edge' made sense on a subatomic scale), its weight (up to a reasonable number of decimals), its location (evidently not that of each of its parts, but possibly an approximate reference to its geometric centre), its temperature (assigning to it an average temperature calculated by the measures at different points), the date and time it was baked, its chemical composition (again using averaged data if the dough was not perfectly uniform), and possibly some other dimensions whose identification and measurement were reasonably possible. It would be much more difficult, even impossible, to describe its smell, the traceability of its components, its commercial appeal, its radioactivity... If such an apparently simple task does not seem feasible, what might we say about dimensions that remain possibly undetectable, whether due to limitations of the technical or biological recording instrument or because they have not yet been discovered? It does not seem very rigorous to deny their existence, or at least the possibility of their existence, and their potential eventual influence, due to the simple fact of being unable to assert their existence.

In view of the above, which must be considered despite falling more in the realm of the philosophy of language, it seems reasonable not to be overly optimistic when attempting to find definitions for these concepts that are, if not irrefutable, at least accepted by a reasonable number of scholars: 'mind', 'intelligence', 'spirit', 'spirituality', 'spiritual intelligence', 'human nature', 'datum', 'coding', 'language', 'energy', 'concrete', 'abstract', and 'reality'. However, accepting this impossibility, we will try to ultimately offer at least one explanation for each of these words that is sufficiently accepted by the academic community, while prudently keeping in mind the conceptual background of Caeiro's input (2018) [3]:

All text is relative. Text is intertext, linking various texts, quotes, ideas... which do not belong to the author; there is only a confluence of stories coming for different cultures. The matrix (screen, fabric, panel) where writing and languages (visual, alphabetical, oral...) are located is an organ with its own entity and will, constructed with threads and scraps taken from different spaces and times of rendering, preventing us from knowing what the true and originating fact is.

CAEIRO, 2018, p. 164

In an area of knowledge as rich in intangible elements as psychology, it does not seem possible to imitate institutions such as the International Union of Pure and Applied Chemistry [IUPAC] in their successful paths towards the design and implementation of an specific international nomenclature; nevertheless, it would be very beneficial for an agency to be eventually created that could, aided by current developments in semantics engineering, big data analytics and artificial intelligence, provide the artificial sciences in general, and the social sciences and educational sciences in particular, with terminology support and a specific glossary explaining the various senses and meanings that different authors, schools of thought, organizations, etc., assign to the most commonly used terms internationally. Nor would it be unreasonable for said desired agency to coordinate the possible creation of neologisms that would enable understanding in the numerous, rather conflicting, situations generated by the abundant polysemy and synonymy of some languages, especially in the use and comprehension of relevant terms.
In any case, the design, creation and implementation of the aforementioned glossary should allow the processing of keywords without sacrificing semantic richness; Rather, it would be about taking advantage of the current possibilities of AI to enrich languages, trying to adapt them to the complexity of reality instead of trying to adapt it, in vain, to a comfortable simplification of the language.

When trying to decipher the meaning of the word 'mind', we find the following definition in the Dictionary of Psychology of the American Psychological Association (APA) [4]:

1. Broadly, all intellectual and psychological phenomena of an organism, encompassing motivational, affective, behavioural, perceptual, and cognitive systems; that is, the organized totality of an organism's mental and psychic processes and the structural and functional cognitive components on which they depend. The term, however, is also used more narrowly to denote only cognitive activities and functions, such as perceiving, attending, thinking, problem solving, language, learning, and memory. The nature of the relationship between the mind and the body, including the brain and its mechanisms or activities, has been, and continues to be, the subject of much debate.

.../...

5. Human consciousness regarded as an immaterial entity distinct from the brain

6. The brain itself and its activities. In this view, the mind essentially is both the anatomical organ and what it does.

\section{APA DICTIONARY OF PSYCHOLOGY Mind}

There is no need to dwell on the term's evident polysemy, with its resulting lack of rigour and its negative consequences in practice.

The concept of 'intelligence' fares no better, continuing to hide its essence from researchers across centuries. Currently, two great 'classical' perspectives basically continue to be in force: Spearman's (1927) [5], which defended the existence of a $g$ factor, as general mental energy, and Thorndike's (1920) multifactor theory [6] about the existence of many different intellectual capacities, developed many decades prior to the popular 'theory of multiple intelligences' now well-known through the media. This dichotomous approach is being overtaken by the more global concept of 'unidiverse intelligence', according to which 'intelligence is singular and multiple at the same time' (Martínez-Otero, 2016, p.119) [7].

Zubiri (1982) offers a broader concept of 'sentient intelligence', stating that "There is no sensing "and" intellection, but merely sentient intellect, an intellect impressing as real what is real' (p.15) [8], thus leading to the consideration of intelligence as part of a whole that intrinsically and essentially includes affectivity. According to this concept, the human bond with reality would cease to be considered exclusively, or fundamentally, an intellective issue. This very interesting approach opens the door to considering intelligence as one simple element in the process of 'communion' (common union) with what is real, thus unleashing possibilities of new, broader relationships than those that must be expressed through codes.

It seems pertinent to mention at this point that 'to educate is to help each human being establish and maintain valuable bonds with reality' (Calderero, Aguirre, Castellanos, Peris, Perochena, 2014, p. 144) [9]. Now we add 'especially with people' (Calderero. Perochena, Peris, 2015, p. 123) [10], where 'each significant word in the proposed statement would be an exponent of a profound semantic load like a meristem generating new concepts and practical didactic applications' (Calderero, Aguirre, Castellanos, Peris, Perochena, 2014, p. 40) [9]. That there is no conceptual restriction regarding those 'valuable bonds with reality', which could be, and are, very diverse and have different characteristics, is understood; unconscious or unknowable bonds cannot be discarded. 
Despite the widespread publication of Gardner's quasi-definition of intelligence, according to which 'human intellectual competence must dominate a set of problem-solving skills, enabling the individual to resolve genuine problems, or the difficulties they face and, when appropriate, create an effective product' (Gardner, 1983, p. 66) [11], we can consider a more 'official' definition of 'intelligence': 'the ability to derive information, learn from experience, adapt to the environment, understand, and correctly utilize thought and reason' (American Psychological Association) [4].

For an understanding of the complexity of the task, we recommend reading the entry for 'intelligence' offered by Ferrater Mora (1965) [12].

There is similar ambiguity regarding the term 'spirit'; such is the volume of synonymy and polysemy for this word that Ferrater Mora (1965) states that "in view of it all, one might wonder if it would not be better to banish the words "spirit" and "spiritual" from philosophy, primarily if we keep in mind that in some modern languages there is confusion between what is "spiritual" and what is "mental" (Ferrater Mora, 1965, p. 572) [12]. The same author states the in numerous cases, spirit (under that same name or others) is understood as something opposed to matter' (Ferrater Mora, 1965, p. 572) [12].

Although the word 'something' might seem to be barely rigorous, its use is reasonable given that the different sciences involved were unsuccessful in being more precise; let us then accept it as being 'something immaterial', while recognising that if we wish to arrive at its ultimate meaning, this is not very illuminating either. Elucidating what 'immaterial' means would be easier if we knew what matter is, but this is not the case because the concept vanishes if we descend, or ascend, to quantum levels. However, as it enjoys a few behavioural features that are somewhat predictable on a human scale and allow us to use it, obtaining previously imagined results, 'matter' is considered something more real, 'objective'. For its 'resonance' with this state of affairs, might we assign to that 'something immaterial' an 'existential status', calling it 'spirit' by observing some of the workings which may be attributed to it?

Even accepting its existence as 'something' distinct from matter, we remain far from having resolved the multiple unknown aspects that arise. For example, if it does not have matter, its nature is not 'suited' to the categories of space or time. Not having matter, it would not have borders, edges. Thus, following a physical analogy, it could not be in a place. Would that mean that 'my spirit' might not necessarily follow me wherever I go? Can my 'spirit' grow old?

At the risk of being daring, we ask ourselves a question whose answer would require a reassessment of certain tenets held very firmly by our rationalistic 'Western' culture, an adjective that clearly lacks sufficient intellectual rigour. Said question would be: Does 'the radical distinction between the sciences of nature and the sciences of the spirit' posed by Dilthey (1883, as cited in Rizo, 2015, p.276) make sense? [13].

In principle, 'spirituality' presents fewer interpretation issues, as its meanings invoke styles of thought, social movements, vital approaches 'per se' more open to diverse interpretation without greater specification apparently being necessary, which is why we shall be content with the definitions provided by the Royal Spanish Academy dictionary:

1. Fem. Nature and condition of spiritual.

2. Fem. Quality of what is spiritualised or reduced to the ecclesiastical condition.

3. Fem. Spiritual deed or thing.

4. Fem. Set of ideas referring to spiritual life.

DICCIONARIO DE LA REAL ACADEMIA ESPAÑOLA (R.A.E.).

Espiritualidad. [Spirituality] [4]
Although it could be said that the concept of 'spiritual intelligence' is an ancient construct, this explicit phrasing is fairly recent and gaining strength in academic literature.

Torralba's (2010) [14] position seems acceptable when he states that there exists in human beings

...a complex series of abilities not present in other vertebrates which allow for the elaboration, with compelling reason, of the hypothesis of a form of intelligence that could be called spiritual.

TORRALBA, 2010, p. 14.

Despite the evident weakness of including in the definition the very term being defined, we cite the following definition for spiritual intelligence: 'the ability to build a healthy (or adaptive) system of spiritual values or beliefs and adopting it as a lifestyle (i.e. adhering to those values)' (Arias \& Lemos, 2015, p. 96) [15]. We do so without, of course, omitting that its characterisation, development, and education constitute a very open subject worthy of exploration' (Torralba, 2015, p. 15) [14].

The currently named 'transhumanist' and 'post-humanist' streams of thought have once again brought to the fore the as-yet-insufficient explanations of what the human being is, and what is proper to him. As witnessed by prior generations, it remains imperative to delve further into understanding human nature and its similarities and differences with other living beings and artefacts that can imitate, and even exceed, human behaviours, as well as thoughts or very similar processes, through artificial intelligence.

\section{Bostrom (2014) [16] defines transhumanism as}

The intellectual and cultural movement that affirms the possibility and desirability of fundamentally improving the human condition through applied reason, especially by developing and making widely available technologies to eliminate aging and to greatly enhance human intellectual, physical, and psychological capacities.

BOSTROM, 2014, p. 1.

This is a definition that, except for the reference to 'eliminat[ing] aging', could practically be applied to any sphere of knowledge; is there any discipline whose aims are not about 'fundamentally improving the human condition'? In light of the controversy and criticism, and the reluctance in various academic and social areas regarding the presumable risk of dehumanisation, the somewhat absurd view that improving humans would be counterproductive could be held. However, it makes sense to be concerned, as there is always danger of interpreting humanity's 'improvement' as an attempt to 'manufacture' a 'superman', an endeavour which has historically ended quite tragically.

Taking another step in the processes of human transformation, we find in Valera and Marambio (2019) [17] that:

The focal point of post humanism consists not so much in the uncritical acceptance of the possibilities offered by technology - as occurs with transhumanism - but rather in a total contamination and hybridisation of human beings with other living beings and with machines.

VALERA \& MARAMBIO, 2019, p. 308.

In this regard, we might ask ourselves whether humans, speaking both individually and collectively, are free or not from interaction with other inanimate, animate, or 'pseudo animate' beings, this latter group being the devices, such as robots, which can imitate typical actions of living beings themselves. We can at least draft some response in the obvious sense that the existence and survival of concrete populations and humans have historically been connected to a greater or lesser extent with available resources and with other populations or individuals. It is not infrequent to find humans who can move, or live, due to the occasional or permanent help of technological artefacts, some of them capable of 'making decisions'. That said, does the existential need for interdependence with others necessarily imply negating an essential humanness? 
Without purporting to define human nature, it seems necessary to accept its existence despite it being a concept currently denied in wide areas of the philosophical arena. We agree with Marcos (2010) [18] when stating that 'Human nature, seen as a limit and restriction, could at the same time be a condition allowing any improvement, at least as its axiological principle' (p. 200); that 'Ultimately, if human nature is completely natural, then it is technically available' (p. 201); and that 'The technical assault on human beings is advocated from these philosophical foundations' (p.201).

Everything seems to indicate the need, the urgency, of moving towards a profound knowledge of what a human being is, because, as stated by Marcos (2010) [18]:

Never, therefore, has the philosophical task of considering human nature itself been so pressing. This will be what will enable us to judiciously apply technologies to therapy and farming. The error is not in technology, rather in its Utopian-futuristic confluence and direction. Never has the consideration of human nature been more pressing, to avoid its very loss along the way to action. And to avoid as well fear-induced Luddite attitudes which paralyse science and technology, and consequently the possibility of the effective improvement of human life.

MARCOS, 2010, p. 203.

Before reflecting on the nature and meanings of a series of other terms that are related to the subject at hand such as "data", "encoding", "language", "energy", "concrete", "abstract", it must be noted that "it seems unworthy of the lowest intellectual rigor to consider that any researched reality must be fully explained through the exclusive application of known methodologies' (Calderero \& Calderero, 2017, p. 52) [19], and that 'we understand that when making the meaning of a term or concept explicit, the use of a form such as "we name ... as X" fits reality better than the usual "X is...". (Calderero \& Calderero, 2017, p. 39) [19]. Assuming both tenets are valid, we intend to leave open the possibility of discovering new unknown realities, new dimensions of known realities or new interpretations regarding realities already studied from other points of view.

\section{A. Datum}

Even in academia, the social custom of considering data as objective elements, devoid of any connotation, and consequently awarding them full credibility, especially if they are of a quantitative nature, seems quite prevalent; however, given that facts and data are realities of a different nature, this custom generates a lack of intellectual rigour and, depending on the social, cultural or intellectual area in which it is applied, can even cause serious damage.

Domínguez (2001) [20] states that:

Data are a cultural product; they cannot therefore be grasped in an aseptic manner. Furthermore, data do not appear, but are rather constructed by us during the research process.

DOMÍNGUEZ, 2001, p. 114.

and that:

The view that all data are "altered" three times: by those who produced them (cultural alteration), by their historical process (post depositional alteration), and by those who interpret them (interpretive alteration). This last alteration is what leads us to conclude that data are always inserted into an interpretative discourse.

DOMÍNGUEZ, 2001, p. 118

In order to indicate at least one difference between a reality and its translation into data, we can use the analogy of the sound possibilities of a piano and those made by a slide trombone or a violin, for example. In the former, only sounds predetermined by the position of the keys may be made, while in the case of the trombone and violin, or similar instruments, it is possible to obtain what could be called a continuous frequency. The formal expression of a datum is necessarily restricted to the expressive capabilities of the measurement instrument used, according to the definition of the construct whose variable value is being determined. It could be concluded that the use of data, despite being necessary to process information, is reductionism.

\section{B. Coding}

If, according to Alegre (2019) [21], coding is transforming information from one type of representation to another (p. 29), then coded information is necessarily different from the original - related to it, in the best of cases by applying a bijection, but different. The object of coding is to adapt information to the interpreting instrument, which necessarily means the impossibility of processing of any information which, by its nature, is not 'understood' by the system that must process it.

\section{Language}

Like any relevant concept, 'language' is not free from synonymy and polysemy, so we must once again recognise the impossibility of a perfect, universal definition of the word, and must settle for a generic meaning that is compatible with a broad range of different 'languages': non-verbal, iconic, musical language, etc., ultimately extending to any system that allows the communication of ideas, facts and feelings.

It is interesting to reflect on what Echeverría (2017) [22] presents as the First Tenet of the Ontology of Language, where:

Language is, above all, what makes human beings the particular type of beings we are. We posit that human beings are linguistic beings, beings that live in language. Language, we postulate, is the key to understanding human phenomena.

It is important to avoid a reductionist interpretation of this tenet that restricts the complexity of human phenomena to language and therefore disregards other non-linguistic dimensions of the human existence. We know that human beings are not just linguistic beings and that, therefore, language does not exhaust the multi-dimensionality of the human phenomenon.

ECHEVERRÍA, 2017, p. 21.

If we accept that language does not exhaust the multi-dimensionality of the phenomenon, we must conclude that neither can it exhaust the complexity of everything real. That is, reality cannot be completely viewed as reflected by any language, any type of representation. What is described and its description are necessarily different, related, but different realities.

In support of this thesis, we cite LEOCATA (2003) [23]:

The constant rethinking of scientific theories, the questioning of what previously seemed immutable, conspire for the logically constructed language to be considered as something both necessary .../... and yet hypothetical, in terms of its correspondence with the real world. We know how we can logically order our language, but that alone does not guarantee knowledge of what the world is like. Thus, for the philosophies of the analysis of language, the old Kantian theme of an unattainable "thing in itself" is reconsidered, what Davidson calls, from the point of view of the philosophy of language, "the inscrutability of reference".

LEOCATA, 2003, p. 288.

\section{Energy, Concrete, Abstract}

By mentioning the concept 'energy', we risk having it considered out of place in this context; however, it is appropriate to deal with it given its possible position as intermediary construct between that which is 'material' and that which is 'spiritual'. Indeed, 'energy' is not 'matter', nor is it 'spirit', but it occupies a substantial role in the lives of humans and, although like those of the other relevant concepts its definitions have weak aspects, it can help us approach our goal of finding analogies and differences between the field of data and the spiritual. 
In attempting to approach, perhaps naively, the concept of energy, we must mention Bunge (1999) [24], who states:

Every science that deals with concrete (or material) things, from physics to social sciences, uses one or more concepts of energy. For example, a psychobiologist wishes to measure the metabolic cost (in calories) of one bit of information transmitted by a synapse; an anthropologist, a sociologist, and an economist are interested in knowing what a community's per capita energy consumption is; they also wish to know whether the members of a given society work in a way that optimises their energy efficiency.

BUNGE, 1999, p. 54

Being ubiquitous, the general concept of energy must be philosophical and, particularly, metaphysical (or ontological); i.e., it is like the concepts of thing and property, space and time, causality and chance, law and trend, and so many others.

BUNGE, 1999, p. 54.

What complicates the problem and sometimes misleads the specialist is that (a) there are as many types of energy as there are large process genres; (b) there are as many concepts of energy as there are general physics theories; (c) the general concept of energy, or just energy, is so general, that it belongs to metaphysics or ontology; and (d) consequently, the general principle of energy conservation is also philosophical, although it has multiple physical roots.

BUNGE, 1999, p. 56.

Accepting the thought-provoking perspective of considering the concept of energy, in one of its meanings, as a metaphysical construct, and therefore worthy of being studied, also, by specialists in philosophy, we can use it as a basis for other concepts such as 'concrete' and 'abstract', so highly relevant to any attempt to understand 'reality'.

Continuing with Bunge (1999) [24], who suggests 'identifying energy with mutability' (p. 54), we quote his postulate 1 , comment 1 , theorem and corollary 1 :

POSTULATE 1: All concrete (material) objects, and only those, are changeable.

In other words: "For every $\mathrm{x}$ : $\mathrm{x}$ is concrete (material) if and only if $\mathrm{x}$ is changeable."

In logical symbols:

Comment 1

We have identified "material" with "concrete." This convention is more customary in philosophy than in physics. According to it, the fields are as material as the stones.

For example, photons are material in the philosophical sense of the word, though they do not have mass, solidity, or their own shape (attributes of matter before the advent of field physics).

From Postulate 1, together with the Definition, it follows that:

THEOREM For every $\mathrm{x}$ : if $\mathrm{x}$ is a material object, then $\mathrm{x}$ possesses energy, and vice versa.

In summary:

Here are two immediate consequences of this theorem. The first is:

COROLLARY 1: Abstract (not concrete) objects lack energy.]

BUNGE, 1999, pp. 54-55.

It seems necessary to recognize that such an approach may be debatable, even if to defend it he has resorted to the use of formal logic, since, for example, the fact that a person changes his mind does not imply that his mind is something concrete.

In this context, we think that we could ask ourselves whether abstract objects have an existential entity beyond human thought, or, in other words, it might be asked whether an abstract "object" can be properly said to "exist".

As an example we show an approach to the concept of geometric point, according to which 'it is an "entity of reason' - i.e. an intersubjective perception with broad consensus - without physical existence', (Calderero 2019) [25]
According to de la Pienda (1992) [26]:

It could be reasoned that: if everything that exists is material, is my concept of the geometric point also material? If everything material is temporal space and, therefore, three-dimensional and changing, how many dimensions does my concept of the geometric point have and what does it change into? If it has three dimensions, then the concept of the geometric point is a contradiction, an absurdity. However, it is a key concept in Euclidian geometry, whose services to science do not seem very questionable.]

DE LA PIENDA, 1992, p. 5.

Despite renouncing the effort to find a satisfactory definition of the basic concept 'geometric point' after an intense study of various sources, we cannot, without seriously violating intellectual rigour, deny that, in some way, 'the point exists', although it seems that its existence is ineffable, and it therefore resists all description.

We have arrived at a critical point in our article: the bonds we humans establish with different real beings (in the broadest sense of what is 'real', not in a reductionist reference to what is only material) are not necessarily linked to a full understanding of their nature. Therefore, we can establish valuable relationships with the different types of realities, inanimate beings, living beings, artifacts, material constructions, concepts, systems, people, etc., without the need to fully understand them or define them with absolute precision. Which does not prevent us from experiencing the need for the, always partial and incomplete, representations of reality to adjust as much as possible to whatever the essence, nature and properties of things are.

After the conceptual revision carried out, and given that it is not possible to define the "spiritual" unambiguously, we are going to make an approach in the sense of trying to clarify the differences between the artifacts moved by AI and the beings that according to different cultural traditions could be considered, at less in part, spiritual and that we dare to call "people". In this sense, in a propaedeutic way, we can mention as characteristic notes of a spiritual being that, at least, is immaterial, irreplaceable, timeless, indelimitable, capable of initiative, responsible, capable of unpredictability. Table I shows us some of these differences.

\section{The "Fuzziness" AND Mutability of ReAlity}

Up to this point, we have repeatedly used the words 'real' and 'reality' without having used any precision to mitigate the quite probable risk that they might be interpreted in different ways.

Without trying to define both words by reverting to reductionism and anticipating our affirmative response to the question 'Is there anything that can be called "reality"?', (Calderero \& Calderero, 2017, p. 99) [19], a few approximations may be outlined in the form of a postulate, which may be useful in communicating somewhat effectively:

- There is something susceptible to being called 'reality'.

- There is 'reality' and there are 'realities'. It is absurd to deny the 'existence' of everything and of something unknown or unknowable.

- The reality of something and its personal or consensual interpretation are different realities.

- The perception and description of a reality are themselves realities, although no coincidence exists between the two or with the reality that is being perceived or described.

- There are subjective realities, the images, concepts, or descriptions (narrative, coded, depicted graphically, and audible, etc.) that one constructs independently, or because of, from existing stimuli.

- There are objective realities whose existence and properties do not depend on human manipulation or interpretation; as an 
TABle i. Some Analogies and Differences Between Devices Driven by AI and Beings with Spirituality

\begin{tabular}{|c|c|c|}
\hline & ...a device driven by artificial intelligence... & $\begin{array}{l}\text {...a being, totally or partially spiritual } \\
\text { (which may be called a 'person')... }\end{array}$ \\
\hline $\begin{array}{l}\text { When communicating with their } \\
\text { surroundings... }\end{array}$ & $\begin{array}{l}\text {...uses codes or predetermined symbols that are } \\
\text { recognisable through its programming. }\end{array}$ & $\begin{array}{c}\text {...can use open procedures with the ability to } \\
\text { improvise and intuit. }\end{array}$ \\
\hline $\begin{array}{l}\text { In their relationship with polysemy and } \\
\text { synonymy... }\end{array}$ & $\begin{array}{c}\text {...cannot process them beyond their most obvious } \\
\text { senses unless it has a huge amount of data and } \\
\text { possible combinations and a very high level of } \\
\text { programming. }\end{array}$ & $\begin{array}{c}\text {...can fluidly utilise connotative and metaphorical } \\
\text { language to proceed, obviously according to the } \\
\text { degree of the person's intellectual and cultural } \\
\text { learning. }\end{array}$ \\
\hline $\begin{array}{l}\text { Regarding its responsibility for its } \\
\text { operations (actions) we can say that... }\end{array}$ & ...has no responsibility. & $\begin{array}{c}\text {...has responsibility as an essential feature, } \\
\text { although it may be greater or lesser according to } \\
\text { certain conditions. }\end{array}$ \\
\hline The 'intelligence' of... & $\begin{array}{l}\text {...is cognitive, only for recognition and } \\
\text { comparison with stored information. }\end{array}$ & $\begin{array}{l}\text {...is cognitive and affective, with no clear } \\
\text { distinction between those dimensions. }\end{array}$ \\
\hline The behaviour of... & ...is predictable. & ...is not always predictable. \\
\hline $\begin{array}{c}\text { When processing, storing, and using } \\
\text { information... }\end{array}$ & ...does so at great speed and with much precision. & ...must exert certain effort. \\
\hline Decision-making for... & $\begin{array}{l}\text {...is fast and neutral, fully restricted to } \\
\text { programming instructions and closed criteria. }\end{array}$ & $\begin{array}{l}\text {...is creative and usually occurs after weighing } \\
\text { repercussions of the decision in other areas, such } \\
\text { as the morality of the actions. }\end{array}$ \\
\hline Regarding moving, acting... & $\begin{array}{l}\text {...can only imitate living beings within the } \\
\text { parameters of its manufacturing and design. }\end{array}$ & ...can be original, unprecedented. \\
\hline The work performance of... & $\begin{array}{l}\text {...is delivered in complete alignment with } \\
\text { requirements and specifications. }\end{array}$ & $\begin{array}{l}\text {...tends to depend on the degree of fulfilment of } \\
\text { certain conditions. }\end{array}$ \\
\hline $\begin{array}{l}\text { Faced with concepts like 'compassion', } \\
\text { 'affection', or such... }\end{array}$ & $\begin{array}{c}\text {...cannot react, as it 'ignores' the concept and the } \\
\text { practice. }\end{array}$ & ...can feel referenced or affected. \\
\hline $\begin{array}{c}\text { Regarding the care of people and things, } \\
\text { contributing to improving humanity and } \\
\text { nature... }\end{array}$ & $\begin{array}{l}\text {...can be very effective if its design and } \\
\text { maintenance are focused in that direction. }\end{array}$ & $\begin{array}{l}\text {...will undertake it as far as their education, } \\
\text { capabilities, beliefs, ideologies, etc. allow. }\end{array}$ \\
\hline $\begin{array}{l}\text { Regarding the construction, use, and } \\
\text { interpretation of data... }\end{array}$ & $\begin{array}{l}\text {...can only move within the limits allowed by its } \\
\text { design and the nature of the information. }\end{array}$ & $\begin{array}{l}\text {...has options that enable them to question all the } \\
\text { related dimensions and imagine new ones. }\end{array}$ \\
\hline Faced with concrete occurrences... & $\begin{array}{l}\text {...cannot act until they have been transformed } \\
\text { into 'understandable' data. }\end{array}$ & $\begin{array}{l}\text {...can act without needing all the information; in } \\
\text { fact, the interpretation, response, and assessment } \\
\text { of consequences can be taken into consideration } \\
\text { at a glance, even if there is difficulty in } \\
\text { describing what happened. }\end{array}$ \\
\hline The language of... & ...must be exclusively denotative. & ...may be connotative, metaphorical. \\
\hline
\end{tabular}

example, any animate or inanimate being whose existence, for millennia, was prior to the development of the human capacity for communication, will suffice.

- It is highly likely that new realities or dimensions, undetected at a given time due to the permanently limited scope of technology and methods to conceive and represent reality, may be discovered, as has always occurred to date.

- The postulate 'In every rigorous scientific investigation, the possibility of the existence of unknown variables, dimensions, realities must be considered' may be deemed legitimate.

- Scientific and investigative work, whose goal consists in advancing towards the discovery of unknown, empirical, conceptual, or any other type of realities, is important. The very nature of research seems to demand the need for institutions to allocate proportionate resources to the study of 'the unknown'.

An inherent difficulty in understanding reality is the paradox that it is reality itself which impedes our progress towards understanding it, because: in each science the ideal is objectivity, but from day to day reality forces us to take into consideration accessible information that is less secure, but employable in our reasoning and in our computers.

KAUFMAN \& ALUJA, 1987, p. 35. [27]

Along these same lines, it is interesting to consider Popper (1976, as cited in Velarde, 1991) [28]:

It is always undesirable to strive to increase precision itself - especially linguistic precision - as it leads, in general, to a lack of clarity and a waste of time and effort in the preliminary stages, which often prove useless as they are overtaken by the actual progress of the matter: one must never try to be more precise than what the situation of the problem demands.

VELARDE, 1991, p. 10.

Furthering this idea, which we might call 'the proportionality of the perceptive-cognitive effort', let us consider what the appropriate distance from which to 'see', or to thoroughly grasp, a painting would be. If we place ourselves at a great distance, we might not even see it physically; as we approach, we will see it increasingly better, until we pass a certain point of inflexion when we will be too near and we 
no longer see it, as our view can only encompass a fragment. This metaphor can probably be applied to the discussion of the degree of specialisation, specification or precision with which one approaches the object of research or investigation. Could it not be that by one's trying to gain precision in the exhaustive control of the process, the object of study was made 'fuzzy' and the loss of perspective made the knowledge sought difficult? The quality of perception of the object of research is not only influenced by the physical or conceptual distance at which the researcher places himself; the excess of data can also impair discernment and the possibility of relevant understanding. In this respect, it is convenient to remember that 'to counter communicationism or an excess of information we propose educating to practice fuzziness' (Caeiro, 2018, p. 170) [3]. This concept of 'fuzziness' is gaining popularity in decision-making in business. Could this concept be an interpretative key that helps to overcome pseudo-dichotomies of usage in the areas of artificial intelligence and spirituality?

In non-specialist fields, there is an excessive tendency to associate artificial intelligence with discrete data, without considering that it is possible to manage relatively diffuse information in AI, since 'fuzzy logic is a branch of artificial intelligence founded on the concept 'it's all a matter of degrees', which allows the management of vague or hard-to-specify information'], (Jerez, Jofré, \& Burgos, 2006, p.11) [29]. In any case, we must remember that, regardless, 'fuzzy logic' continues to move within limited fields that allow handling 'fuzzy sets' whose edges are less defined than those of conventional sets, but that exist; they continue to require mathematical formalisms.

Uncertainty, "approximateness", are an essential part of scientific knowledge; no one doubts that the results of scientific investigations are merely statistical, despite which it is frequent in science teaching to present theories to students as closed, indisputable postulates; today, for example, it is still taught in classrooms that in the absence of application of a non-balanced force (Fnet $=0$ ), an object at rest remains at rest, and an object in motion remains in motion with constant velocity (constant speed and direction)'] (Wilson \& Buffa, 2003 , p. 106) [30]. This principle enjoys huge credibility among students and professors, given its 'unequivocal verifiability'; the statement can be proven true sufficiently reliably in any teaching laboratory, since the experimental data can be considered 'evidence'. However, when the assertion is taken to its ultimate end, there exists precisely the problem that nobody, ever, has been able to prove it more than apparently, and only by using relative terms, always referring to systems considered theoretically immobile. The concept 'at rest' is a theoretical construct, as is the situation of an 'absence of application of a non-balanced force'; it rather seems that any material particle, no matter how minute, is never at rest and cannot not be subjected to any force. If it is impossible to even consider that the components of solid material substances are at rest, or for it to be appropriate to do so with extensive objects, since as they necessarily turn with the Earth and it around the Sun and the Sun also moves, it seems legitimate to conclude that physical reality is continuously changing. We could say that mutability is an essential property of reality. Additionally, chemical transformations are continuous processes which, by their very nature, cannot cease to occur at any time.

On the other hand, it would not be rigorous to omit from any study of reality the influence that intangible 'human spirit' elements have on its configuration. Without delving too deeply, one can deduce that all large and small human works owe their existence to the fact of having been conceived, at least broadly, in a human mind; it seems the creative process goes from the idea, an intangible, to a practical realisation. Everything seems to indicate that there is a strong bond, which is difficult to detect and make concrete operationally, between immaterial realities (without physical substance) and concrete material realities.

We resist accepting as indisputable the postulates of those scientific currents that maintain that human mental activity is completely explained by biochemical or bioelectric processes, closing the possibility of existing to other dimensions that cannot be processed by the instruments and methods of experimental science. We agree with Artigas (1984) [31] when he states that:

The experimental science approach assumes a point of view in which the kinds of things that can be said, and therefore the kinds of entities that can be found, are predetermined. Concretely, experimental science does not extend, in principle, to spiritual realities; therefore, denying the spirit on the basis of these sciences is unsustainable scientism.

ARTIGAS, 1984; quoted in ÁLVAREZ, 2019, [32], p. 61.

Perhaps human creativity is something more than just the original, unprecedented, unique response capacity to different stimuli and we should consider the need to accept the existence of "fields of consciousness". In this sense, assuming the possibility that they may be considered questionable, it is appropriate not to discard, and reflect on, the contributions of Grof (1999) [33]:

Newtonian science is responsible for having offered us a very limited vision of human beings and their true potential. For about two hundred years it has dictated the criteria of what constitutes an acceptable experience and what is an unacceptable experience of reality. From its viewpoint, a 'normal' person is that which is capable of reproducing exactly the external objective world described by Newtonian science. Consequently, from that perspective, our mental functions are limited to receiving information provided by our sensory organs, storing it in the 'memory banks of our mental computer', and recombining the sensory data to create something new. Any significant departure from that perception of 'objective reality' - a consensual reality that the general population considers the only truth - is interpreted as the product of a runaway imagination or a mental disorder.]

GROF, 1999, p. 18.

Instead of speaking of discrete objects and empty spaces between them, today the universe is considered to be a continuous field of variable density. According to modern physics, matter is interchangeable with energy, and conscience - which is not limited to activities taking place inside our skull - forms a part of the same fabric of the universe.

As the British astronomer James Jeans said over sixty years ago, the universe of modern physics resembles more a great thought than a giant super machine.

GROF, 1999, p. 20.

From these ideas, we could deduce that:

There seems to be no possibility of creating a better world through the mere outside intervention that does not include a deep transformation of human conscience.

GROF, 1999, p. 308.

Taking as a reference the last two quotes, it does not seem necessary to demonstrate that the activity of personal beings, persons, such as human beings is significant when studying the transformations that physical reality experiences, because for over two million years humanity has had tools, coarse and fledgling yet useful, to accomplish diverse tasks. Since the dawn of prehistory, this tendency to transform reality has only grown. The current challenge is to delve into the psychic influence exerted by the human mind on other persons or animate beings. In the extremely vast field of human interactions one can observe, even at a glance, the influence that the mere presence of a person exerts on the thoughts, words and behaviour of others.

Assuming the aforementioned disparity exists between reality and its various representations, and considering that all life depends in large measure on the intellectual development of human beings, it stands to reason that it is of great interest that relevant decisionmaking should avoid the many reductionisms abounding in intellectual 
circles, and whose consequences are suffered in all spheres - personal, family, social, political and economic. In this sense, we venture to propose the creation, and their use in research and instruction, of indicators, or failing that, clarifiers, to be used as correction factors when introducing in theories inherent in different sciences sufficient elements of uncertainty that 'invite' the consideration of the possible presence of unknown variables and the subsequent in fieri nature of any knowledge or scientific discovery. We deem it would be highly profitable, in all senses of the word, to promote a questioning of the many blindly assumed and disseminated topics, distancing ourselves as far as possible from the sense of writings published by Cervera University in 1827 to King Ferdinand VII, of Spain:

Far from us this dangerous novelty of thinking (reflecting), which has caused harm for a long time, finally rupturing, with undeniable effects, tainting custom, totally disrupting empires and religion in every part of the world.

GACETA DE MADRID, núm. 53, p. 211. [34].

This is an explicit statement which, despite being in the distant past, continues to inform certain areas of academics, albeit more subtly; proof of this might be found in the solemn declaration that is pronounced by the rector in several Spanish universities when awarding the academic cap to new doctors:

Receive the Book of Science which it is your duty to teach and advance, and let it be a sign and a warning to you that, however great your ingenuity, you must render obedience and reverence to the doctrine of your teachers and predecessors.

At the risk that it might be considered a 'contradiction in terminis', we believe it would be very convenient, and maybe necessary, to lay the foundation of a possible branch of epistemology, 'administration of the unknown' without which it seems unlikely that 'the unknown' could become known. The attitudes, strategies and protocols that could lead to discovering, exploring, formalising and in that case utilising unknown but maybe intuited dimensions, beings or relationships, are worthy of consideration as a relevant element of research, even in those cases when results are not foreseeable in the short and medium term.

\section{THE INTERDIMENSIONAL UNITY OF REALITY}

Despite accepting the huge difficulty, even impossibility, of associating unequivocal meaning to the term 'reality' and being aware of the 'fuzziness' of the concept and of 'conceptualised objects', we will reflect on two of its possible qualities: it is multifaceted (multidimensional) and has intrinsic and essential unity.

According to the Royal Spanish Academy dictionary [35], 'dimension' is:

1. Fem. Aspect or facet of something.

2. Fem. Measure of magnitude in one direction.

3. Fem. Physics. Each magnitude that fixes the position of a point within a space.

4. Fem. Physics. Each of the fundamental magnitudes: time, length, mass, and electrical charge, which express a physical variable.

DICCIONARIO DE LA REAL ACADEMIA ESPAÑOLA (R.A.E.)

Dimensión

We once again perceive the lexical inadequacy we must necessarily work with in our efforts to reach significant progress in detecting reality, in its processing, and in the development of valuable links that might overcome the limitations of any representation system.

In the arena of the previously poorly-named 'exact sciences', there are also similar ambiguities to be found:

The concept of dimension can be considered of great importance in mathematics, because it is a source for understanding other concepts in that discipline, but it is also difficult to conceptualise due to its complexity in being defined, as well as considering that inside mathematics it is used in various ways depending on the area where one is working.

PÁEZ, ORJUELA, \& ROJAS, 2008, p. 1. [36]

The matter becomes complicated when trying to define the meaning of 'dimension' in moral, linguistic, economic, political, artistic arenas, and others. We are faced with a term with a considerable degree of polysemy. Add to this complexity the fact that the different 'dimensions' an object 'has', be it physical or not, probably only exist in the collective mind of the scholars that have coined the corresponding constructs.

Without seeking to demonstrate it, we point out that the history of human knowledge seems to endorse the idea that every being or construct can be contemplated from different angles and analysed from such different views as the ones evaluating the existence or not, and the degrees, of its 'size', 'position', 'weight', 'colour', 'chemical composition', 'economic value', 'symbolic significance', 'deterioration', 'origin', 'evolution', 'morality', and so many others that it would be improper, and impossible, to try to list here. In accordance with this idea, it would seem reasonable to broaden the object of study of the different sciences in order to avoid excessive focus on the study of certain areas considered as belonging to a few disciplines and 'nonexistent' in others. To that effect, it would behove us all to reflect on the eventual benefits of favouring, at least at high levels, interdisciplinary, interfacultative research, and consequently, teaching.

Conversely, is it acceptable that, in examining the same object of study, researchers of various disciplines arrive at incompatible conclusions, and that both are considered correct? Wouldn't it be more reasonable to consider that some of the research or the paradigms or the theories considered, or all of them, must be revised until the incompatibility is removed, or until it is proven that it was only apparent, or new theories were generated that could align said disparate results conceptually or operationally? If, as presumably will occur, we accept the reasonability of the preceding statement of noncontradiction, we are somehow assuming the unity of reality, which we might identify as 'unidiverse', echoing the statement by MartínezOtero (2009) [37] with their 'theory of unidiverse intelligence', in which intelligence is presented as 'a unitary and multiple faculty' (p. 1)

Assuming the suitability of encouraging interdisciplinary synergy, it would be appropriate to consider the benefits of broadening the current widespread, and lauded, STEM paradigm, an acronym for science, technology, engineering, and mathematics, recommended for students as future 'professional outlets', to a more inclusive STEAM that incorporates an A for 'arts', in line with Maeda (2013) [38], who holds that:

Design creates the innovative products and solutions that will propel our economy forward, and artists ask the deep questions about humanity that reveal which way forward actually is.

Government agencies are beginning to acknowledge that art and science - once inextricably linked, both dedicated to finding truth and beauty - are better together than apart.

MAEDA, 2013, p.1

There are some authors, far from settling for science and art being better together than apart, who suggestively propose to 'broaden the categories of science and technology to those of art' (Caeiro, 2018, p. 168) [3]. We feel that, dispensing with the rhetorical format of the statement, it offers great depth, understanding that it attempts to alleviate the reductionist effect of the limited scientific paradigm to the study of the section of reality detectable by human senses and by what we might consider their 'extension', technology. By broadening the categories of science and technology to those of art, we understand that they would be enriched by the deep, and mysterious, intangible, 
and spiritual elements of art, not only with the aesthetic, harmonious elements of algebraic expressions used in a great portion of scientific content, but with aesthetic aspects that are not minor due to the importance of beauty in human life, and not reducible to pragmatic, utilitarian aspects without loss of dignity.

On the other hand, it should be pointed out that, since artistic practice is a human activity we could describe as essential, the term 'arts' can also be interpreted as 'humanities', which leads us to overcome the possibly artificial barrier that separates 'sciences' from 'humanities'. Therefore, we should cease to consider them as a kind of 'benevolent concession' to be necessarily incorporated into academic, political or economic life in order to 'humanise' it so it does not appear to be too cold or 'stark'. According to the classic concept, the constant progress towards knowledge requires the seven liberal arts, as expressed by De la Iglesia (2001) [39]:

Mercury, fulfilling his duty as husband, presented Philology with the principle dowry of his divine wedding gift: seven wise servants to help his beloved to continue her constant progress towards knowledge. Three of them (Grammar, Rhetoric, and Dialectic) would attend to perfect her internal world; the other four (Arithmetic, Music, Geometry, and Astrology) would enable a wider understanding of the external world.

DE LA IGLESIA, 2001, p.131

In line with reality's interdimensional unity, we understand that studies that lead to its illumination should be interdimensional 'per se', so that the conjunction of research instruments and methods can guarantee a minimum of interdisciplinary synergy, by which the risk of conceptual and methodological reductionism can be reduced as much as possible. To that end, we understand that from the onset of their studies the instruction of young students and researchers should have a 'fractal' nature, so that the desired interdisciplinary synergy for academic and research projects does not become a requirement implanted a fortiori, but a natural consequence of the global mentality personally acquired by each young person from the earliest age. We understand that in this presumably desirable process of interdisciplinary instruction, artificial intelligence will be called upon to occupy a relevant role by enabling the processing of enormous quantities of data, simultaneously showing the convergence and divergence among them, and enabling what we might call a 'macro hyper-textual and hyper-relational' language; thus, by considerably reducing the task of searching for information, encouraging intellectual activities that are less mechanical and more oriented towards deeper and intangible aspects of human beings.

Paraphrasing Moreno, Carrasco, and Herrera Viedma (2019) [40] when they state that ' $\mathrm{t}]$ he main objective of this work, therefore, is to define a formal framework that allows market orientation to be effective in the context of big data' (p. 7), we feel that a desirable challenge would be to define a framework that would allow human activity's spirit orientation to be effective within the context of big data.

Furthering the required synergy between the areas pertaining to data and those corresponding to the spirit and humanities, we agree with Lope Salvador, Mamaqi and Bordes (2020) [41] regarding the need to put into

\footnotetext{
...perspective three large matters: 1) the need to update the set of digital competencies for the efficient analysis of massive amounts of data as the basis for the professional profile of the cyber-analyst; 2) the assumption that AI is offering new epistemological opportunities in social sciences and humanities that must be leveraged; and 3) the implementation of procedures derived from AI for the effective analysis of the content of scientific publications when evaluating quality and innovation.]
}

SALVADOR, MAMAQI, \& BORDES, 2020, p. 85

\section{CONCLUSIONS}

After having carried out the planned conceptual review of some relevant terms, and having reflected both on the concept of "reality" and its "fuzziness" and on its interdimensionality and unity, and with the intent of contributing to a greater integration of human knowledge in the pursuit of a better quality of life, as understood in all possible senses and not only as relates to physical wellbeing, we summarise below some of the possible conclusions that could be drawn.

Regarding AI, we consider that:

- With its enormous power for data processing, it can be greatly helpful in alleviating, where possible, the proverbial lexical insufficiency related to spirituality, psychology, philosophy and the humanities in general.

- It can be enormously helpful in highlighting the eventual lack of foundation of all the principles, axioms, or postulates of a philosophical, moral and spiritual nature whose main, or only, value resides in their high degree of dissemination in the media, and which are uncritically assumed by many and often socially enforced. Semantic engineering could be a magnificent tool for discriminating the genuinely spiritual from bastard concepts likely attributed to the spirit or the spiritual despite possibly having a different, even fraudulent, origin.

- It can generate codes, labels, morphology and syntax capable of processing great volumes of information with many significant nuances that can be placed 'above' the human mind's level of understanding and handling. Thus, overcoming conventional languages, they can establish other valuable links with reality, interacting with it without the reductionisms that conventional languages might insert.

- It can help to design, or design directly, instruments for interpreting reality that are more 'empathetic' with its intangible aspects, or taken as such.

Regarding it being interdisciplinary, we believe it would be highly beneficial for humanity and nature, and therefore in mutual benefit of a desirable environmental balance, that:

- In areas related to spiritual instruction, religious or not, and in educational institutions, academia, especially in universities specialising in humanities, sufficient knowledge of the nature, properties, and scope of science, technology, and, concretely, artificial intelligence, should be promoted so that, particularly the new generations might perceive the eventual mutual benefits to be derived from working together, abandoning the paradigm of suspicion of the dehumanisation that many people attribute to technology. It would be beneficial if, in the study of scientificexperimental fields, and in university degrees, intellectual rigour were sufficiently encouraged, so that new generations being educated would avoid the reductionism of viewing as the only valid sources of knowledge those that exclusively use data.

- It would be very positive for human and environmental development to take significant steps towards the creation of interdisciplinary, interfacultative, interuniversity teams of research that would study in depth, and with the most advanced AI techniques, how to integrate the methodologies pertaining to generating knowledge (broadly) corresponding to experimental areas with those of non-experimental areas, especially those centred on the study of the intangible.

We understand that the scope of these conclusions is not limited to the eventual interest of specialists in AI and Sciences of the Spirit but may be useful for students of disciplines such as Linguistics, Psychology, Philosophy, Morals, Theology and Educational Sciences. 
REFERENCES

[1] Naciones Unidas. Transformar nuestro mundo: la Agenda 2030 para el Desarrollo Sostenible. Resolución de la Asamblea General A/71/1, aprobada el 25 de septiembre de 2015. http://www.un.org/ga/search/ view_doc.asp?symbol=A/RES/70/1\&re-ferer=/english/\&Lang=S

[2] Francisco. Carta Encíclica Laudato Si' del Santo Padre Francisco. Sobre el cuidado de la casa común. Mayo, 24 de 2015.

[3] Caerio, M. "Ser persona en la sociedad del conocimiento y el espectáculo". Arte y políticas de identidad, 18, pp. 159-176, 2018, doi: https://doi. org/10.6018/reapi.336061.

[4] APA Dictionary of Psychology. Disponible en https://dictionary.apa.org/.

[5] Spearman, C. The Abilities of Man: Their Nature and Measurement. New York, USA: McMillan, 1927.

[6] Thorndike, E.L. "Intelligence and its Uses". Harper's Magazine, 140, $227-$ 235. 1920.

[7] Martínez-Otero Pérez, V. "Alcance socioeducativo de la teoría de la inteligencia unidiversa”. Holos, vol. 5 (), pp. 116-126. 2016, doi: 10.15628/ holos.2016.4731.

[8] Zubiri, X. Inteligencia y logos (Vol. 2). Madrid, España: Alianza Editorial. 1982

[9] Calderero, J. F., Aguirre, A. M., Castellanos, A., Peris, R, Perochena, P. "Una nueva aproximación al concepto de educación personalizada y su relación con las TIC." Teoría de la Educación. Educación y Cultura en la Sociedad de la Información, vol. 15, no. 2, pp. 131-151. 2014, doi: https:// doi.org/10.14201/eks.11890.

[10] Calderero, J. F., Perochena, P. y Peris, R. "Estudio integrador de elementos significativos en la formación de maestros. Una propuesta para la autoevaluación docente”. Tendencias pedagógicas, vol. 25, pp. 121-148. 2015.

[11] Gardner, H. E Frames of Mind. The Theory of Multiple Intelligences. Nueva York, Basic Books. 1983. Versión castellana: Estructuras de la Mente. La Teoría de las Inteligencias Múltiples. México, Ed. Fondo de Cultura Económica, 2001.

[12] Ferrater Mora, J. Diccionario de Filosofía $5^{\circ}$ edición Editorial Sudamericana. Buenos Aires, Argentina. 1965.

[13] Rizo-Patrón de Lerner, R. "Reconsiderando la relación entre la naturaleza y el espíritu”. Escritos de filosofía, no. 3, pp. 265-287. p. 276. 2015.

[14] Torralba, F. Inteligencia espiritual. Barcelona, España: Plataforma Editorial. 2010

[15] Arias, R., \& Lemos, V. "Una aproximación teórica y empírica al constructo de inteligencia espiritual". Enfoques, vol. 27, no. 1, pp. 79-102, 2015.

[16] Bostrom, N. "Introduction-The Transhumanist FAQ: A General Introduction" in Transhumanism and the Body (pp. 1-17). New York: Palgrave Macmillan, 2014.

[17] Valera, L., \& Marambio,J.T. A. Posthumanismo e hibridación. Pensamiento Revista de Investigación e Información Filosófica, 75(283 S. Esp), pp. 307319, 2019, doi: https://doi.org/10.14422/pen.v75.i283.y2019.016.

[18] Marcos, A. "Filosofía de la naturaleza humana". Eikasia. Revista de Filosofía, vol. 6, no. 35, pp. 181-208, 2010.

[19] Calderero Hernández, J. F., Calderero de Aldecoa, A. Filosofía y sentido común. Madrid, España: Sekotia. 2017.

[20] Domínguez Berenjeno, E. L. "Arqueología y territorio: de la 'interpretación arqueológica' al 'dato histórico". SPAL, Revista de prehistoria y Arqueología de la Universidad de Sevilla vol. 10, pp. 109-122, 2001, doi: http://dx.doi.org/10.12795/spal.2001.i10.05

[21] Alegre Ramos, M.P. Sistemas operativos monopuesto (2a ed.). Madrid, España: Paraninfo. 2019.

[22] cheverría, R. (2017). Ontología del lenguaje. Buenos Aires, Argentina: Ediciones Granica SA.

[23] Leocata, F. (2003). Persona, lenguaje, realidad. EDUCA.

[24] Bunge, M. "La energía entre la física y la metafísica". Revista de Enseñanza de la Física, vol. 12, no. 1, pp. 53-56. 1999.

[25] Calderero J. F. jfcalderero.wordpress.com. (27 de abril de 2019). ¿Existes o eres invención humana? https://jfcalderero.wordpress.com/2019/04/27/ existes-o-eres-invencion-humana/

[26] de la Pienda, J. A. "Cientifismo marxista". Espíritu: cuadernos del Instituto Filosófico de Balmesiana, vol. 41, no. 106, pp. 167-184. 1992.

[27] Kaufman, A., \& i Aluja, J. G. Técnicas operativas de gestión para el tratamiento de la incertidumbre. Barcelona, España: Hispano Europea. 1987.
[28] Velarde, J. Gnoseología de los sistemas difusos. España: Servicio de Publicaciones de la Universidad de Oviedo. 1991.

[29] Jerez López, P., Jofré Nuñez, C. y Burgos Letelier, D. "Lógica borrosa aplicada en ADR de Europa, Asia y Latinoamerica". Ph.D. dissertation, Facultad de Economía y Negocios, Universidad de Chile, Santiago, Chile, 2006.

[30] Wilson, Jerry D., Buffa Anthony J., Lou, Bo. Física. (5ª ed.) México: Pearson educación. 2003.

[31] Artigas, M. (1984). Máquinas pensantes y conocimiento humano. En Actas del III Simposio de Teología Histórica (7-9 mayo 1984). Confrontación de la teología y la cultura. Valencia: Facultad de Teología San Vicente Ferrer. p. 392.

[32] Álvarez-Álvarez, J. J. (2019). Apuntes para el repensamiento de la enseñanza de la Arquitectura. La cuestión epistemológica y la necesidad de una razón ampliada. Revista de Arquitectura, vol. 21, no. 2, pp. 57-67.

[33] Grof, S. La mente holotrópica. Barcelona, España: Kairós. 1999.

[34] de Madrid, Gaceta. 3 de mayo de 1827. Gaceta de Madrid, núm. 53.

[35] REAL ACADEMIA ESPAÑOLA: Diccionario de la lengua española, $23^{\mathrm{a}}$ ed., [versión 23.3 en línea]. https://dle.rae.es

[36] Páez, J., Orjuela, C., \& Rojas, C. (2008). "El concepto de dimensión: errores y dificultades" in $9^{\circ}$ Encuentro Colombiano de Matemática Educativa. Valledupar, Colombia, 2008.

[37] Martínez-Otero Pérez, V. "Propuestas educativas derivadas de la teoría de la inteligencia unidiversa". Revista Iberoamericana de Educación, vol. 50, no. 1. 2009, doi: http://dx.doi.org/10.35362/rie5011851.

[38] Maeda, J. "Stem + art= steam". The STEAM fournal, vol. 1, no. 1, Art. 34. 2013, doi: http://dx.doi.org/10.5642/steam.201301.34

[39] de la Iglesia, J., "Las artes liberales en la Biblioteca Real del Escorial: dos antecedentes iconográficos". In El Monasterio del Escorial y la pintura: actas del Simposium, 1/5-IX-2001 (pp. 119-164). Real Centro Universitario Escorial-María Cristina, El Escorial, España, 2001, pp. 119-164.

[40] Moreno, C., González, R. A. C., \& Viedma, E. H. (2019). "Data and Artificial Intelligence Strategy: A Conceptual Enterprise Big Data Cloud Architecture to Enable Market-Oriented Organisations". International Journal of Interactive Multimedia and Artificial Intelligence, vol. 5, no. 6, pp. 7-14. 2019, doi: http://dx.doi.org/10.9781/ijimai.2019.06.003

[41] Salvador, V. L., Mamaqi, X., \& Bordes, F. J. V. ”La Inteligencia Artificial: desafíos teóricos, formativos y comunicativos de la datificación". Icono14, vol. 18, no. 1, pp. 58-88, 2020.

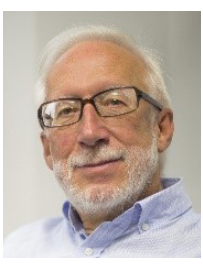

José Fernando Calderero Hernández

José Fernando Calderero Hernández is a Doctor of Philosophy and Educational Sciences (Complutense University of Madrid, Spain. 2003) and has a degree in chemistry (University of Salamanca, Salamanca, Spain. 1972). He is currently a professor of "Theory and Practice of Educational Research" and "Life Cycles and Communication in the Family" at the International University of La Rioja (UNIR), President of the Education Chapter of AEDOS and Vice President of the Foundation "Parents for Excellence, Padrex". He has been Dean of the Faculty of Education of the UNIR, Deputy Director of the Education Area of the Villanueva University of Madrid, professor of the University of Navarra and of the Bachelor of Education of the University of Wales, speaker in courses for teachers and managers in Spain and America, with a professional performance of 27 years as a manager and university professor and 24 years as a director and teacher of high schools. He has written several educational books and academic articles and supervised some doctoral theses. His lines of work and research are focused on personalized education, family education and the development of critical sense. 